\title{
Factors Impacting Capital Structure in Indonesian Food and Beverage Companies
}

\author{
Prof. Dr. Euphrasia Susy Suhendra (Gunadarma University, Indonesia)
}

\begin{abstract}
Capital structure is directly related with the financial decision of the company. Capital structure theories seek to explain why businesses choose different mixes of debt and equity to finance their operations. The concept is generally described as the combination of debt \& equity that make the total capital of firms. It usually comprises all the sources of finance that a company is utilizing to finance its operations. The aim of this study is to know the major determinants of capital structure, the factors that affect capital structure. This study has used the data from 17 food and beverages Indonesian firms over a time period of 3 years (20010-2012). Debt to equity ratio (DER) is a dependent variable which is defined as the ratio of total debt to equity of the observed company, and there are five independent variables, which are liquidity, profitability, asset tangibility, firm size, and firm growth. As a result of this study, there are two variables that have a significant effect toward Capital Structure in sector of Food and Beverages Companies; they are Liquidity and Asset Structure with significant negative correlation. The other three remaining independent variables which are Profitability, Firm Size, and Asset Growth do not have significant effect toward the Capital Structure in sector of Food and Beverages Company.
\end{abstract}

\section{Introduction}

The term "capital structure" of a company is actually a combination of equity shares, preference shares and long-term debts. A cautious attention has to be paid as far as the optimum capital structure is concerned. With unplanned capital structure, companies may fail to economize the use of their funds. Consequently, it is being increasingly realized that a company should plan its capital structure to maximize the use of funds and to be able to adapt more easily to the changing conditions. (A. Hovakimian, T. Opler, and S. Titman, 2009)

Capital structure is directly related with the financial decision of the company. Capital structure theories seek to explain why businesses choose different mixes of debt and equity to finance their operations. The concept is generally described as the combination of debt \& equity that make the total capital of firms. It usually comprises all the sources of finance that a company is utilizing to finance its operations. Usually, capital structure is made up of ordinary share capital, preference share capital, and debt capital amongst others. It shows how a company finances its overall operations and growth by using different sources of funding. Capital structure of companies varies with its size, type and some other characteristics such as age of the company, company size, asset structure, profitability, company growth, company risk and liquidity (Al-Najjar and Taylor, 2008). Specifically, the influential factors in determining how firms select the types of security to be issued are considered to be questionable.

One of the most important decisions faced by financial managers in relation to the continuity of the company's operations or financial decision-making is capital structure, which is a financial decision relating to the composition of the debt with equity elements that should be used by company. Manager should be able to raise funds, either sourced from within the company or outside the company efficiently.

The purpose of managing capital structure is to mix the financial sources in order to maximize the wealth of shareholders and minimize the company's cost of capital. Therefore, one of the financial manager's responsibilities is to manage and decide the optimal capital structure for the purposes. His or her decision on capital structure could be critical because it may affect the company values and it involves a trade-off between risk and return. A rise in debt will increase the company's risk and the expected return. High risk means an increase in debt which could lead to a decrease in stock price and an increase in the expected return of stock price (Brigham and Houston, 2001). Hence, the motivation of an optimal capital structure is to ensure the balance between risk and return in order to maximize the stock price (Brigham and Houston, 2001).

The food and beverages sub-sector industry has an important role in Indonesia's economic growth. Minister of Industrial of Republic of Indonesia stated that the food and beverages sub-sector industry plays an important role in industry development, especially in the contribution of gross domestic product (GDP) of Non-Oil \& Gas Industry in Indonesia.

The reason of choosing food and beverages sector industry is because food and beverages stock is the most resistant stock among the other sectors when faced with the economic crisis. Food and beverages products are still needed in every condition, whether it is in a crisis condition or not. This company's product is often highly used and consumed, and is able to stand in every capital structure policy that company has made. Thus, even how bad the capital structure decision within company can be, it is almost to be ensured that the products will still have consumers buying for it, the products therefore are needed very much by consumer. If the production activities are hampered it will interfere other company activities that will cause losses. Company therefore must 
strengthen the internal factors in order to keep growing and sustain, one of the way is managing and maintaining the capital structure properly to maximize the wealth of the firm, more specifically shareholder's wealth maximization. To maximize firm's value as well as minimize the cost of fund, a manager should set up an optimal capital structure.

Capital structure on food and Beverages Company encounters instability, thus in financing the business, inappropriate capital structure does not result in an ideal composition of capital structure. The problem in determining capital structure decision is how to mix between debt and equity in the company's capital structure that will influence its market value. Food and beverages companies have a high composition of capital structure (DER), characterized by a high level of total debt to total equity.

According to the problems that have been formulated, then the purpose of this research are as follows, (1) To analyze the relationship of selected factor like profitability, liquidity, asset structure, firm size, and asset growth on capital structure (Total Debt to Equity Ratio) of foods and beverages company listed on Indonesian Stock Exchange; (2) To know which variable has the greatest influence on capital structure of food and beverages company

\section{Literature Review}

The term capital has several meanings and it is used in many business contexts. Capital is something owned which provides ongoing services. In general, capital is accumulated assets or ownership. More specifically, capital is the amount of cash and other assets owned by a business. These business assets include accounts receivable, equipment, and land/buildings of the business. Capital can also represent the accumulated wealth of a business, represented by its assets less liabilities. The definition of capital according to Brigham (2006:62) is "capital is the sum of long-term debt, preferred stock, and common stock equity, or maybe those posts plus shortterm debt charged by interest."

Capital structure has been defined as the proportionate mix of debt and equity. Basically, the essential elements of capital structure are debt and equity. Keown et. al (2005) stated that debt is an amount owed to a person or organization for funds borrowed. Debt can be represented by a loan, bond, mortgage or other form stating repayment term. Meanwhile, equity is an ownership interest in a corporation, it could be a common stock or preferred stock. It also refers to total assets minus total liabilities, in another case it is shown as shareholder's equity.

Sartono (1999), financial structure is proportion between total liabilities and total equity that are shown on the balance sheet. Scott, Petty, Martin, and Keown whose writing piece was translated by Sulistyorini and Djakman (2000), financial structure is proportion between liabilities - equity that required as specification by company management. Gitman (1997), capital structure is the mix of the long-term debt and equity maintained by the firm.

According to Brigham \& Ehrhardt (2008) capital structure refers to the firm mixture of debt and equity. Therefore, a value-maximizing firm will establish an optimal capital structure and then raise new capital to target this optimal capital structure over time (Brigham and Ehrhardt 2008). According to Devic and Krstic (2001), Capital structure is expressed as ratio of long term liabilities to the sum of long term liabilities and firms' equity. Capital structure is described as long term debt divided by total assets (Omet, 2008; Delcoure, 2007). The origin and combining two types of capital determines to a considerable extent financial stability and strength to pay the company's long-term debt (RahnamaRoudposhti et al. 2006, p. 352).

The capital or ownership of a business can be evaluated by knowing how much of the ownership is in debt and how much in equity. The company's debt might include both short-term debt and long-term debt (such as mortgages), and equity, including common stock, preferred shares, and retained earnings. Capital structure is sometimes referred as a company's debt to equity ratio.

The information on capital structure is essential for every stakeholder of a firm to make their decisions pertaining to the firm. Suitable capital structure is not only imperative for maximization of interest of every stakeholder of an organization, but also crucial for the organization to compete effectively and efficiently in its operating environment (Simerly and $\mathrm{Li}$, 1999). Capital structure decision is also affected by firm's characteristics. These characteristics are potentially contentious (Titman and Wessels 1988). Each theory of capital structure gives different implications on how the firm's characteristics influence the firm's capital structure choices.

Literature has stated that various external and internal factors affect the capital structure of corporate organizations. The external factors include factors such as tax policy, capital market conditions and tax policy, among others. Meanwhile, the internal factors are those which are related to individual firm characteristics. Capital structure theories have identified a wide range of internal factors which are potentially influential toward capital structure choice. Reference identified some of these internal factors to include which are firm size, profitability, assets tangibility, taxation, firm growth rate, and liquidity. However, many researchers found that 
the factors affecting capital structure vary from one country to the other due to a variation in the level social, environmental, economical, technological and cultural development. As a result of this, findings from studies in one country cannot be reasonably generalized to other countries.

It has been theorized in the literature that firms may actually have more debt in their capital structure than is appropriate for two reasons. First, higher levels of debt align the interests of managers and shareholders (Harris and Raviv, 1991). Second, managers may underestimate the costs of bankruptcy, reorganization or liquidation (Gleason et al., 2000). Both of these factors suggest higher than appropriate amounts of debt in the capital structure.

\section{Research Methodology}

Population is the subject of research which has the least same properties. The population in this research is food and beverages companies listed on IDX period 2010-2012.

Samples can be interpreted as a part or representative population studied. The sampling technique that is used is Purposive Sampling. Purposive sampling is a technique to obtain and determine the sample with a certain consideration and specific criteria. Population of this research is food and beverages sector of manufacturing company listed in Indonesian Stock Exchange for period 2010-2012. A total of 19 food and beverages companies have been collected. Purposive sampling method is used to collect sample. This research used 17 samples of food and beverages companies of food and beverages sector, starting from 2010 until 2012.

Capital Structure has been uniquely taken as the dependent variable here. It indicates that the mix of equity financing and debt financing do support the assets side of the company's balance sheet. Debt to equity ratio (DER) is taken as a dependent variable which is defined as the ratio of total debt to equity of the observed company. This research uses five independent variables, which are liquidity, profitability, asset tangibility, firm size, and firm growth.

This model is chosen because the purpose of this research is to determine the independent variables which have the effects toward dependent variable. Simple regression model is used to analyze the relationship between two variables, independent variable (x) and dependent variable (y). The equation of multiple regression analysis is as follow:

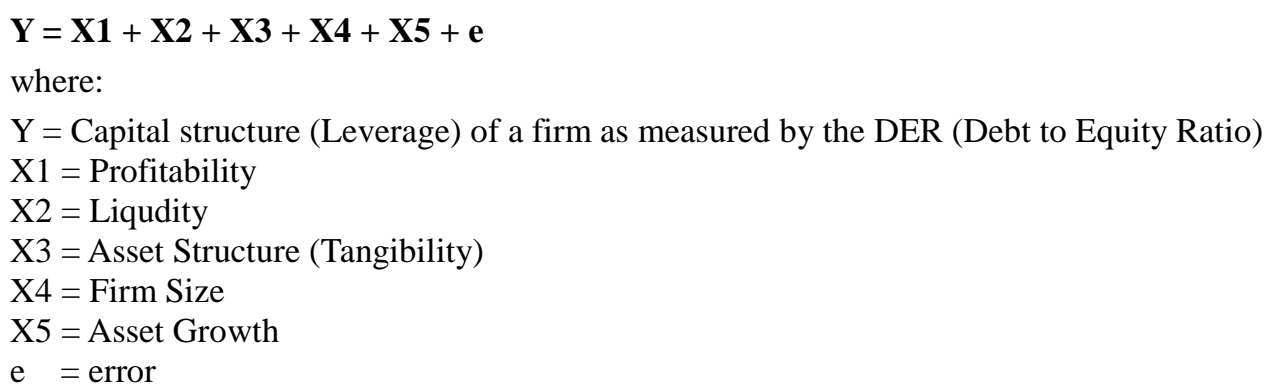

\section{Result and Discussion}

The first analysis was done to analyze the data by using descriptive statistic which describes all variables of the research. Descriptive statistics result shows the minimum and maximum value of each variable and also the mean and standard deviation of the variables.

The variables of this research are liquidity, profitability, asset tangibility (asset structure), firm size, asset growth and capital structure as measured by DER. General description of these variables appears on table 4.1 below:

Descriptive Statistics

\begin{tabular}{|l|r|r|r|r|r|}
\hline & $\mathrm{N}$ & Minimum & Maximum & \multicolumn{1}{c|}{ Mean } & Std. Dev iation \\
\hline Liquidity & 51 &, 58 & 6,33 & 1,9240 & 1,11918 \\
Prof itability & 51 &, 02 &, 42 &, 1209 &, 09047 \\
Asset_Structure & 51 &, 13 &, 74 &, 3500 &, 14918 \\
Firm_Size & 51 & 25,41 & 31,71 & 28,1676 & 1,57639 \\
Asset_Growth & 51 &,- 07 &, 91 &, 2474 &, 22982 \\
DER & 51 &, 19 & 2,49 & 1,0349 &, 57990 \\
Valid N (listwise) & 51 & & & & \\
\hline
\end{tabular}

Table 4.1 Descriptive Statistics. 
Normality test is conducted with a statistical analysis which is a non-parametric One-Sample KolmogorovSmirnov (KS Test) in order to find out whether the residual value is normally distributed or not. The results of the analysis using histograms and normal probability graphs plot can be seen in Figure 4.2 and Figure 4.3 as follows:

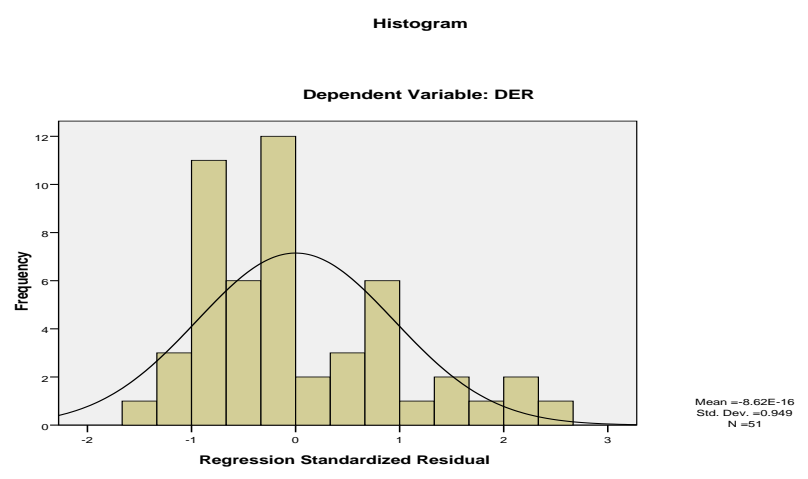

Figure 4.1 Histogram and normal probability

Histogram in Figure 4.2 shows that the data has a normal distribution pattern (indicated by a bell-shaped curve).

Normal P-P Plot of Regression Standardized Residual

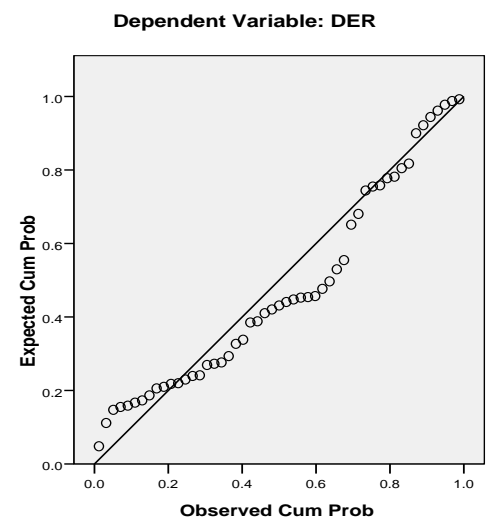

Figure 4.2 Normal PP Plot of Regression Standardized Residual

The graph shows the normal probability plots coincide with the point spread around the diagonal line and follow the direction of the diagonal line. It means that it is normally distributed. Besides using analysis graph, normality test is conducted with a statistical analysis which is a non-parametric One-Sample KolmogorovSmirnov (KS Test) as follows:

One-Sample Kolmogorov-Smirnov Test

\begin{tabular}{|ll|r|}
\hline & & $\begin{array}{r}\text { Unstandardiz } \\
\text { ed Residual }\end{array}$ \\
\hline N & & 51 \\
Normal Parameters ${ }^{\text {a,b }}$ & Mean &, 0000000 \\
Most Extreme & Std. Dev iation &, 47296602 \\
Diff erences & Absolute &, 153 \\
& Positive &, 153 \\
Kolmogorov-Smirnov Z & Negativ e &,- 095 \\
Asy mp. Sig. (2-tailed) & & 1,094 \\
\hline
\end{tabular}

a. Test distribution is Normal.

b. Calculated from data.

Table 4.2. Kolmogorov Smirnov Test 
Based on table 4.2 above, it can be seen that when Asymp. Sig (2 - tailed) is greater than the criteria of significance ( $\mathrm{p}$-value) 0,05 , this proves that the variable is normally distributed, where the test results are consistent with the analysis of histograms and normal probability graphs plot. It shows that all of the independent variables used are normally distributed.

Multicollinearity test is used to determine whether the regression model is found to have a correlation between independent variables. Multicollinearity test is done by calculating the variance inflation factor (VIF) of each independent. VIF values must be less than 10 and the tolerance value is more than 0,1 . The value of VIF and tolerance value are available in Table 4.3 below:

Coefficien $\mathbf{t s}^{\mathrm{a}}$

\begin{tabular}{|ll|r|r|}
\hline \multirow{2}{*}{ Model } & \multicolumn{2}{|c|}{ Collinearity } & Statistics \\
\cline { 3 - 4 } & & Tolerance & \multicolumn{1}{c|}{ VIF } \\
\hline 1 & Liquidity &, 722 & 1,385 \\
& Prof itability &, 897 & 1,115 \\
& Asset_Structure &, 671 & 1,490 \\
& Firm_Size &, 895 & 1,117 \\
& Asset_Growth &, 875 & 1,142 \\
\hline
\end{tabular}

a. Dependent Variable: DER

Table 4.3. Multicollenearity Test

The table 4.3 shows all the variables do not have a problem with multicollinearity because the value of tolerance is more than 0,1 and the value of VIF is less than 10 . It can be concluded that there is no multicollinearity in the regression model.

Autocorrelation test aim is to know whether a correlation between the residual in $\mathrm{t}$ period ant $\mathrm{t}-1$ period. Autocorrelation test is done by calculating the value of the Durbin-Watson. The value of dW for five independent variables with 17 samples is 1.7701 and the $\mathrm{dW}$ is 2,115 . The value of Durbin-Watson is shown in table 4.4 below:

\begin{tabular}{|l|r|r|r|r|r|}
\hline Model & $\mathrm{R}$ & R Square & $\begin{array}{c}\text { Adjusted R } \\
\text { Square }\end{array}$ & $\begin{array}{c}\text { Std. Error of the } \\
\text { Estimate }\end{array}$ & Durbin-Watson \\
\hline 1 &, $579(\mathrm{a})$ &, 335 &, 261 &, 49855 & 2,115 \\
\hline
\end{tabular}

a Predictors: (Constant), Asset Growth, Firm Size, Liquidity, Profitability, Asset Structure

b Dependent Variable: DER

Table 4.4. Autocorrelation Test

Table 4.4 shows the value of Durbin-Watson is 2,115 . Since the value of Durbin-Watson is the region with no autocorrelation, which is located $\mathrm{dU}<\mathrm{dW}<(4-\mathrm{dU})$. Thus, it means no autocorrelation.

Heterocedasticity test is used to determine whether or not the regression model has a constant variance from the residual one to another observation.

The aim of using multiple regression analysis is to know the influence of the independent variables affect dependent variables.

Coefficients

\begin{tabular}{|ll|r|r|r|r|r|}
\hline & & \multicolumn{2}{|c|}{$\begin{array}{c}\text { Unstandardized } \\
\text { Coeff icients }\end{array}$} & $\begin{array}{l}\text { Standardized } \\
\text { Coeff icients }\end{array}$ & & \\
\cline { 3 - 5 } Model & & \multicolumn{1}{|c|}{ B } & Std. Error & \multicolumn{1}{c|}{ Beta } & \multicolumn{1}{c|}{ Sig. } \\
\hline 1 & (Constant) & 2,686 & 1,435 & & 1,872 &, 068 \\
& Liquidity &,- 331 &, 074 &,- 638 & $-4,462$ &, 000 \\
& Prof itability &, 775 &, 823 &, 121 &, 942 &, 351 \\
& Asset_Structure & $-1,438$ &, 577 &,- 370 & $-2,492$ &, 016 \\
& Firm_Size &,- 025 &, 047 &,- 067 &,- 520 &, 606 \\
& Asset_Growth &, 353 &, 328 &, 140 & 1,077 &, 287 \\
\hline
\end{tabular}

a. Dependent Variable: DER

Table 4.5. Multiple Regression T-Test Result 
After testing the influence of each independent variable towards the dependent variable, the following will present the influences of all independent variables on the dependent variable. The following table presents the calculation:

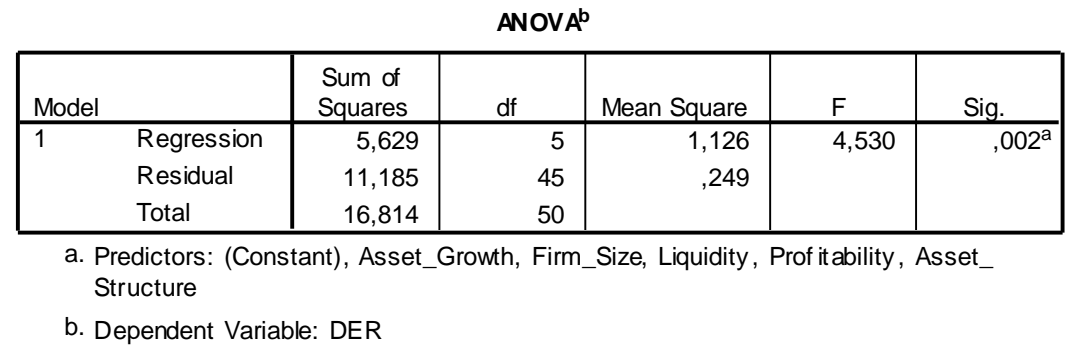

Table 4.6. Multiple Regression F-Test Result

The results of calculations using SPSS above show that the value of $F_{\text {count }}$ is 4,530. This value is greater than the value of $F$ table for 2,422. Similarly, the probability of significance for the model formulated in this study is 0.002 . This value is smaller than 0.05 so it can be concluded that the variables of liquidity, profitability, asset structure, firm size, asset growth simultaneously affect DER at a confidence level of 95\% ( $\alpha=5 \%)$.

To determine the amount of variation in the dependent variable can be determined from the value determination. The strength of influence between independent variable and dependent variable can be seen from coefficient of determination value $\left(\mathrm{R}^{2}\right)$ that is in range between $0-1$. If the value is close to 1 , thus it means that the independent variables almost give all of the information needed to predict the variation of dependent variable (Ghozali, 2005).

Model Summary

\begin{tabular}{l|c|c|c|r|}
\hline Model & $\mathrm{R}$ & $\mathrm{R}$ Square & $\begin{array}{c}\text { Adjusted } \\
\text { R Square }\end{array}$ & $\begin{array}{r}\text { Std. Error of } \\
\text { the Estimate }\end{array}$ \\
\hline 1 &, $579^{\mathrm{a}}$ &, 335 &, 261 &, 49855 \\
\hline \multicolumn{4}{|c|}{ a. Predictors: (Constant), Asset_Growth, Firm_Size, } \\
Liquidity, Prof itability, Asset_Structure
\end{tabular}

Table 4.7. Determination Test Result

The coefficient of determination $\left(\mathrm{R}^{2}\right)$ of 0,335 implies that simultaneously $33,5 \%$ DER is influenced by liquidity, profitability, asset structure, firm size, asset growth, government ownership and public ownership. While $66,5 \%$ are influenced by other variables or other factors outside the model.

Capital structure is the financial decision of every firm. Every firm must decide the optimal proportion of debt and equity in order to have a maximum firm value. Usually, capital structure is measured by debt to total assets ratio, equity to total assets ratio, and debt-equity ratio. Appropriate (optimal) capital structure decisions would increase and maximize the market value of the share of a company. According to numerous researches, capital structure decisions are determined by a complex set of factors (Chen, 2004; Mazur, 2007; Bhabra, Liu \& Tirtiroglu, 2008; Frank \& Goyal, 2009; Getzmann, Lang \& Spremann, 2010).

Capital structure can be explained by all of the independent variables. The explanation of each variable is

\section{Liquidity}

In this research, liquidity variable has a significant influence towards DER, whereas it can be concluded from the coefficient regression that liquidity has negative relation with capital structure. It means that lower asset liquidity reduces the costs of debt, and as a result, companies use more debt.

Myers and Rajan (1998) and Morellec (2001) argued that the effect of asset liquidity on leverage is positive only when managers have no discretion over firm assets, which reduces the risk of wealth expropriation (e.g., assets serve as collateral for debt). Williamson (1988) and Shleifer and Vishny (1992) argue that more liquid assets increase optimal leverage. Williamson (1988) also posits that assets that are more liquid, or more "redeploy able" should be financed with debt more often, because banks and public debt markets incur lower costs from financing these assets. That is, liquid assets are less costly to monitor and liquidate for bondholders. Therefore, higher asset liquidity increases the amount of capital firms that can be borrowed, as well as the optimal leverage. This positive relationship is consistent with the tradeoff theory, assets with high liquidation value and lower expected bankruptcy costs can support more debt and should be positively related to debt ratios.

\section{Profitability}

In this research, profitability variable has no significant influence towards DER whereas it can be concluded from the coefficient regression that profitability has a positive relation with capital structure. Although there is 
no significant effect, a positive relationship between profitability and DER shows that there is a positive tendency that the higher profit is obtained, it is likely that company prefers using more external financing. To absorb the required capital, companies are forced to generate enough profit to provide good return for investors and creditors. Long-term sustainability of a company depends on its ability in generating income for meeting all the obligation and providing good return for major shareholders.

The findings are not considered to support pecking order theory that the effect of profitability is negative and statistically significant. Higher profitability firms tend to have less debt. Based on pecking order theory, in a case with asymmetrical information between manager and outsource investors, managers prefer financing from internal sources to external ones, where external finance is costly and where retaining earnings as liquid assets serve a precautionary motive.

According to this theory, if external finance is required, the first choice is to issue debt, hybrid, and then eventually equity as a last resort. Companies with less profitability ask for loan. This behavior may be due to the costs of issuing new equity, as a result of asymmetric information or transaction costs. All things being equal, the more profitable the firms are, the more internal financing they will have.

\section{Asset Structure}

In this research asset structure variable significantly affects capital structure. Asset structure is negatively related to DER while the tradeoff theory predicts tangibility to be positively related to debt levels for two main reasons, namely security and the costs of financial distress. First, tangible assets normally provide high collateral value relative to intangible assets, which implies that these assets can support more debt. Second, tangible assets often reduce the costs of financial distress because they tend to have higher liquidation value. Assets that are tangible are more desirable from the point of view of creditors because they are easier to repossess in bankruptcy states.

According to the pecking order theory and the trade-off theory, a firm with a large amount of fixed asset can borrow at a relatively lower rate of interest by providing the security of these assets to the creditors. Having the incentive of getting debt at a lower interest rate, a firm with a higher percentage of fixed asset is expected to borrow more as compared to a firm whose cost of borrowing is higher because of having less fixed assets.

\section{Firm Size}

In this research firm size has no significant effect to capital structure while firm size has been empirically found to be strongly positively related to capital structure. Many studies on capital structure suggest that there is a positive relationship between leverage and size of the firm.

Large firms may be able to take advantage of economies of scale in issuing long-term debt, and may even have bargaining power over creditors. So the cost of issuing debt and equity is negatively related to firm size. In addition, larger firms often diversify their financing sources and have more stable cash flows, hence have lower variance of earnings, making them able to tolerate high debt ratios (Castanias, 1983; Titman and Wessels, 1988; Wald, 1999), and so the probability of bankruptcy for larger firms is less, relative to smaller firms.

\section{Asset Growth}

In this research, asset growth has no significant effect to capital structure. There is a positive relation between asset growth and DER. It is explained that growth orientation for company is needed to raise capital (equity investment) from external sources, because company does not have enough its own resources or cannot access loans.

However, many investor are reluctant to invest in start-ups and innovative firms because of the high risks and transaction costs, or because the estimation that the expected returns will not compensate for the risk. The problem of investment is about the tendency by highly levered firms to pass up profitable investments. The reason for this is that when debt levels are high, investors are reluctant to provide further equity funds because they are aware of the fact that cash flows which are generated from investments will go to service debt before any is returned to them.

The greater the asset of a company is more likely to make a profit. Greater company's profits would certainly increase the value of the assets as well and it can continue to convince the creditors of the company. It is based on the belief of creditors on funds invested in the company secured by the amount of assets owned by the company.

\section{Conclusion}

The starting point for understanding the concept of capital structure is that the companies own assets that are generated by its process and investment activities. Appropriate capital structure decisions will minimize the cost of capital and increase firm's value. Therefore, it is important for the firm's manager to understand the theory of capital structure. 
Based on the analysis and discussion that has been done in the previous chapter, it can be concluded several things as follows:

1. From the five (5) independent variables there are two (2) variables that have a significant effect with Capital Structure in sector of Food and Beverages Company; they are Liquidity and Asset Structure with significant negative correlation. And the other remaining three (3) independent variables which are Profitability, Firm Size, and Asset Growth do not have significant effect towards Capital Structure in sector of Food and Beverages Company.

2. According to F-Test, it is found that all five (5) independent variables altogether have a significant influence on Capital Structure in sector of Food and Beverages Company.

\section{References}

- Hovakimian, T. Opler, and S. Titman “The Debt-Equity Choice, Journal of Financial and Quantitative Analysis", vol. 36 (1), pp. 1-24, 2001.

- F. Modigliani, and M. H. Miller "The Cost of Capital, Corporation Finance and the Theory of Investment", American Economic Review, vol. 48 (3), pp. 261-297, 1958.

- J. Hughes, J. Liu, and J. Liu, "Information Asymmetry, Diversification, and Cost of Capital", The Accounting Review, vol. 82 (3), pp. 705-729, 2007.

- J. J. Chen, "Determinants of capital structure of Chinese-listed companies", Journal of Business Research, vol. 57, pp. 1341-1351, 2004.

- M. Dragota, “Analiza factorilor determinanti ai politicii de finantare a societatilor comerciale listate pe piata de capital", unpublished.

- L. Booth, V. Aivazian, A. Demirgüc-Kunt, and V. Maksimovic, "Capital structure in developing countries", Journal of Finance, vol. 56, pp. 87-130, 2001.

- $\quad$ M. J. Barclay, and C. W. Smith Jr., “On Financial Architecture: Leverage, Maturity, and Priority, Journal of Applied Corporate Finance, vol. 8 (4), pp. 4-17, 1996.

- $\quad$ M. Z. Frank, and V. K. Goyal, "Testing The Pecking Order Theory of Capital Structure”, Journal. of Financial Economics, Vol. 67, pp. 217-248, 2003.

- Pandey, "Capital Structure and the Firm Characteristics: Evidence from an Emerging Market", unpublished.

- S. C. Myers, R. Brealey, and S. Schaefer, “Term structure with uncertain inflation”, Journal of Finance, vol. 32, pp. 277-89, 1977.

- T. C. Lim, "Determinants of capital structure empirical evidence from financial services listed firms in China", International Journal of Economics and Finance, vol. 4 (3), pp. 192-203, 2012.

- T. I. Eldomiaty, "Determinants of corporate capital structure: evidence from an emerging economy", International Journal of Commerce and Management, vol. 17 (1/2), pp. 25-43, 2007. 